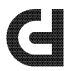 \\ COUNTERFUTURES \\ Left thought \& practice Aotearoa
}

\section{THREE}




\title{
In the Car
}

\author{
Pip Adam
}

INCE WE'VE BEEN teaching creative writing in prisons,
we've spent a lot of time in cars. We teach in pairs, which
has been extremely important to the sustainability of our
work, and prisons are generally a long way from town. So we
tend to go together. One of us will pick the other up from outside
our house or outside a café or beside some other landmark and to
begin with we'll talk about non-work things-TV shows, books,
films, family—-but inevitably the talk turns to the workshop
ahead of us. In this way our cars have become moving offices. We
discuss the workshop for the day, often changing and adapting
our approach. A large part of this talk is developing 'Plan B's
which we have found to be an extremely important part of teach-
ing in the changeable feast which is prison. William Brandt and I
have been teaching exclusively remand prisoners for the last two
years. Remand is where people go to await trial or sentencing in 
custody so it is by nature a fluctuating and transient group. Plan B's tend to be our Plan A's.

One particular day, a sunny but cold day in June this year, I was in a car with William, Gigi Fenster and James George who teaches creative writing at Auckland Prison on Auckland's North Shore. Gigi and William had been teaching at Unit 9 in Rimutaka Prison, a special treatment unit for prisoners with a history of violent offending. It's a place where men who want to change go. There's a structured nine-month course which balances treatment and activities that offer different ways of expressing and dealing with emotions that arise in the everyday. To celebrate the end of the creative writing course, the therapists at Unit 9 had organised a presentation of some of the work the men had produced over the three months Gigi and William had been working with them. Gigi and William invited me to come to the presentation and we invited James down from Auckland to be a guest writer. William had picked us up on Courtney Place and we were travelling along State Highway 2 toward Upper Hutt where Rimutaka Prison is located.

We're coming to realise more and more that these celebrations are really important to the work we're doing. For one thing they put an end to the course. 'You have completed' is a powerful message to people who may not have enjoyed success in conventional educational situations. They celebrate the commitment that has been given to the work and the course. At Arohata, where William and I teach, recognition of this kind of completion is problematic. Generally, except at the end of each year, participants don't finish together. People leave and people arrive and often this happens between writing workshops. William and I have adapted the idea of 'graduation' to reflect this and the certificates we give out tend to celebrate 'Your progress so far' rather than 'You have finished'. Often women would think they were going home only to have bail denied and find themselves 
back at creative writing the next week, so we tend to celebrate other milestones other than 'completion' with these certificates. 'Congratulations on getting that poem you've been working on for a few weeks to a version that you're happy with'. 'Well done on sorting out that plot problem'. 'Yay us, for completing a really compelling collaborative work'. In my experience, there is a strange 'market' that operates in prison. Material objects take on values that are not immediately obvious to someone outside the particular prison community. I remember fifteen or so years ago giving a tailor-made cigarette to a prisoner who put it behind their ear and rolled a cigarette to smoke with me there and then. I remember a woman begging the librarian for some stickers in the shape of dots. They weren't stars or red or anything that seemed interesting to me, but this woman wanted them so badly. While there is almost certainly an alternative economy going on in the prison-this being traded for that-I also think there is some intrinsic value which possibly the women associate with their own value in these objects. So if we can give a woman a certificate or a card or a notebook it is often a huge thing and a tangible record of her work.

One of the big deals for the presentation at Rimutaka was that the volunteer co-ordinator had organised some food which we suspected would ensure a good turnout. As we drove down the motorway-Gigi and me in the back, James and William in the front-Gigi read out the plan for the presentation. There was discussion about where in the programme James would read. Gigi and William had planned an 'open mic'. There were other men writing in the unit, not just the ones from Gigi and William's creative writing workshop. There were also musicians and at the last presentation some of the staff had read writing of their own.

'If you read before the open mic', Gigi said, 'I wonder if it will intimidate people and they won't read'. 
Determining our place and the place of our writing in the prison workshops has been an evolving issue since we started. During workshops, William and I tend to do the writing exercises we set with the women. I'm not sure of William's motivation, but I began doing this because I couldn't handle sitting in silence twiddling my thumbs while the women wrote and wrote. I suspect though it has more to do with something we heard Chris Barrand, a tutor at Pablos Arts Studio, say at an Arts Access workshop. Arts Access Aotearoa/Whakahauhau Katoa o Hanga advocates for people in New Zealand who experience barriers to participation in the arts, as both creators and audiences. The workshop was dealing particularly with facilitating the creation of art in prisons and Chris had talked about 'de-centring' himself in these processes, of trying consciously to take himself as much as possible out of the conventional role of 'teacher' - a classroom set-up that had probably not succeeded with many of the people with whom he was working.

This chimed with our experience of creative writing workshops we had attended and taught in academic settings. William, Gigi, and I had all been students and facilitators at the International Institute of Modern Letters (IIML) at Victoria University. We had all experienced facilitators, especially of the MA, with a zen-like quality of taking themselves 'out of the picture' and so encouraging the room to have its say. There is a real ethos at the IIML of letting the work be the work it wants to be, rather than the work the facilitator thinks it should be, which also seemed important for teaching in a prison context. By us all being writers together in the room, rather than a teacher/student dichotomy, it was possible for the work to become what it needed to become. When William or I offered feedback we offered it as part of the room not as owners of special or secret knowledge. Art and especially creative writing lends itself to this type of teaching so well. All of the women we teach are readers or watchers 
or story-tellers so they know what excites them, what they want to read more of, therefore everyone's opinion is equal and necessary. This type of environment also seems to build confidence which leads to a willingness to work slightly outside a comfort zone which is often where writers develop best. To say to a room full of people who have, by their own admission, made poor life choices, 'There is no wrong way to do this', is an empowering thing.

There were occasions where William or I might talk about a craft point-point of view, say, or tense-and in these instances we may start the lesson more like a traditional class. William or I at a whiteboard perhaps, writing 'Dog bites man' underlining subject, object, verb. But even these very quickly levelled out. Often there were women in the room who understood grammar as well if not better than us. One was an English teacher, one a $\mathrm{PhD}$ candidate. So even these more formalised classes very quickly became about everyone sharing knowledge with each other. Something William and I encouraged enthusiastically. I found this very exciting. The reason I wanted to teach creative writing in prisons wasn't because I believed in its power as part of rehabilitation (although I have become convinced that it does have some benefits), but because of a desire to see writing in Aotearoa/New Zealand from a broader base. I was interested in hearing new voices, of seeing new voices in print. So this idea of letting the work and the writer develop without too much of my intervention was really powerful for me. Rather than someone from 'inside' the mainstream literary community shaping work to look like writing that already existed, I was excited that through changing the workshop room we could encourage work that was distinct and new.

The other week William and I were setting up for a lesson at Arohata prison and I said, 'I feel more and more aggression any time I hear or read someone pointing to something and saying, "This is good writing". That term "good writing" gives me 
the fantods at the moment'.

William said, 'Yeah, there's no such thing as bad writing, just unfinished writing, writing that hasn't been worked on enough'.

After that conversation I realised what I wanted was to offer the conditions that allow someone to work on something 'long enough' so it arrives at a form that says what they want to say in a way that feels true to them. I also relish the opportunity to encourage my ear to learn to hear a different literary aesthetic.

So William and Gigi and James talked in the car on the way to Rimutaka about where best to put James' reading in the programme. If James read before the open mic would it stop other people from volunteering their work? Or was it better that they heard his work before they volunteered their own? So they knew who was in the room? I suddenly felt bad that I hadn't brought any writing, and I realised that this is often how writers whakapapa. We show our work to show where and how we're grounded, what we call home creatively.

By about Avalon Gigi, William, and James had decided how the presentation would run.

'So the order then', Gigi was writing as well as reading, William was driving, I was probably eating almonds. I'm generally stress-eating almonds whenever we're driving to a prison. I still get ridiculously anxious, not for my personal safety any more but for the risk of embarrassment in someone else's whare. That I'll say something wrong, that I'll sit in the wrong place. James turned so he could hear Gigi better. 'I'll introduce. Then $\mathrm{L}$ will read, then $\mathrm{D}$ will read, then $\mathrm{M}$ will introduce the collaborative poem they wrote together. Then William will introduce James. Then James will read and speak. Then James will introduce the open mic. Then we'll have a Q and A. Then we'll close up and have some kai'.

We all liked that plan. 
From somewhere, I think it was someone asking James what he was going to read, William mentioned that at the threeday course he and I had run the week before at Arohata, we read out loud a lot more than usual and it was received really well. William had brought Hone Tuwhare's Mihi, and Bill Manhire's My Sunshine as possible Plan B's.

'They brought lunch halfway through our second hour', I said. 'And of course, no one was keen to keep writing, so instead, William read poems to them and we talked about them'.

Gigi told us her mother, who was a speech and drama teacher, had read to her and her sisters well into their twenties. I talked about my daughter and how she 'reads' all her fiction as audio books. 'Stephen Fry reads her Harry Potter', I said. 'David Tennant How to Train Your Dragon'.

William said he was sure the feedback was more involved and livelier than in the past when everyone had read published work quietly to themselves and were then asked what they thought.

James said he was sure it had something to do with the seeming sanctity of books. That people saw writing on the page as something concrete, complete, sacred so were much less likely to comment on it. Something about this rang true. 'We all talk', he said. 'We all tell stories about our daily lives and we all comment on each other's ways of telling these stories. It's really natural. So if someone reads a poem I think people are more likely to feel able or allowed to comment on it than if it is in black and white in a book'.

'One thing I hate though', William said.

'Boy do you hate it', I interrupted knowing where this was going.

'Is when actors read fiction'.

William and I had talked a lot about how great the New Yorker Fiction podcast was and how writers were the best read- 
ers of fiction and this seemed to be true whether or not the writer had written the work they were reading.

James wondered if it had something to do with interpretation.

'Yeah', said William. 'Like actors approach a text thinking something is missing but a writer approaches it thinking it's complete and they just need to stay out of its way, so their delivery is less performed'.

'How does Hamlet fit'? I said.

After Curt Tofteland from Shakespeare Behind Bars had visited New Zealand, and we'd attended one of his workshops, William and I decided to give the Bard a go at the Arohata remand wing creative writing workshop. William has been to drama school and I had managed to do an entire English degree without studying one of Shakespeare's plays. So he took the lead. It was a pretty incredible thing to be in the room for. As William offered a plot summary it occurred to me that this was possibly the first time I'd heard people talk about Hamlet who truly knew what was at stake. For most people murder and revenge are abstract ideas but in this room they were lived experience. The women volunteered quickly to take roles and read, and soon after were reading with metre and gave some great performances. It was as if the oddness of the language meant they were approaching it more like music than words in a way that encouraged them to read sound rather than meaning. We also all found the opacity of the language quite entertaining and some of the words very funny.

After we'd finished the scene and William had explained what had happened in the scene, the women began to relate Hamlet and Ophelia's plight to their own experiences. 'Is it like when a guy's cheating on you and he tries to tell you you're crazy for thinking he is'? 'Is it like when you know you're in trouble and you don't want to bring trouble on anyone you love'? From this, 
in the best Plan B way, William asked if it would be fun to write the scene in a modern setting, one they knew, one from their life. The results were some of the best writing any of the women produced. They wrote the one-act plays and performed them the next week, some of them rehearsing in between on the wing and in their cells at night.

'I just realised', I said. 'Hamlet was probably the first time we read out loud in any real way'.

'Yeah', William said.

'Was it the reading out loud or was it Shakespeare?' I said. I was pretty sure it was Shakespeare, but, I said jokingly, 'We need a control'. 
If you like what you have read, please subscribe or donate.

\author{
G \\ COUNTERF UTURES \\ Left thought \& practice Aotearoa \\ (C) Copyright Counterfutures 2017
}

